\title{
Leadership Effectiveness in Nepalese Service Organizations
}

\author{
Dipesh Upadhyay
}

\begin{abstract}
Leadership is important for Nepalese managers today than ever due to globalization and increasing competition. The findings show leadership has near to moderate level of effectiveness in Nepal which means it is under-utilized as indicated by the variable taken for this study i.e. vision, empowerment, communication, task/relationship orientation and locus of control scales.
\end{abstract}

Key words: leadership, vision, empowerment, communication, task and relationship orientation, and locus of control

LEADERSHIP HAS ALWAYS BEEN CRITICAL to organizational effectiveness or performance and vice versa. This paper has outlined five independent variables i.e. vision, communication, empowerment, task or relationship orientation and locus of control among so many that could affect leadership effectiveness in order to compete in a global and dynamic world.

Oswald, Stanwick, and LaTour in the year 1997 found that strategic vision had a positive impact on organizational performance in highly competitive environment. Researchers like Baum, Locke, and Kirkpatrick in 1998 also reported quality of vision had a positive effect on venture growth in entrepreneurial settings. A different set of studies conducted by Doz and Prahalad in 1987; Coulson-Thomas in 1992; Larwood, Falbe, Kriger, and Miesling in 1995 indicated that the content of the vision played a critical role in the ability to change an organization. Conger in 1989 noticed that effective leaders knew when people felt powerful (empowered); they were more willing to make the decisions and take the actions needed to get their jobs done. Shashkin in 1982, and 1984; Kanter, in 1983; Greenberger and Stasser, in 1991; and Spreitzer in 1992 in their studies showed that empowered employees were more productive, more satisfied and innovative and creating higher quality products and services than non empowered employees. Katz and Kahn in 1978 found managers often spend between 50 percent and 90 percent of their time talking to people. Schermerhorn Jr. (2004) noted 30 percent or more of managers reported difficulties in dealing with communication and interpersonal relations. Morley, Shockley-Zalaback and Cesaria in 2002 found organizations with conducive communication processes were more effective in achieving their task related goals and had more positive working environments, as perceived by their employees. Markowitz and Levering in 2002, in their analysis of the top 100 UK corporationsfound out that those communicated well were most effective. Ohio State Studies and University of Michigan Studies conducted during 1930s and 1940s found out that task and relationship orientation can be useful while predicting leadership effectiveness. According to the researchers relationship oriented leaders are more effective. Blake and Mouton in 1964 while developing the Managerial Grid encouraged leaders to examine their own style on two dimensions: task and relationship. They assumed that leaders can be high on both, low on both or high on one and low on the other. Effective managers also exhibited more relationship oriented behaviors which included demonstrating trust and confidence, 
acting friendly and being considerate, showing appreciation, keeping people informed, and so on. Rotter in 1966 was pioneer to propose the concept of locus of control for the first time. He developed most commonly used scale to assess locus of control construct. Blau in 1993 identified managers with internal locus of control did better at job tasks requiring initiative, but externals did better in highly structured routine tasks. As shown by Spector in 1994 internal locus of control is also correlated with better adjustment to work in terms of satisfaction, coping with stress, and job involvement (The Blackwell Encyclopedic Dictionary of Organizational Behavior, 1995, p. 298). Spector believed that internality was associated with high levels of effort, motivation, job performance and job satisfaction that tended to exhibit initiative on the job and preferred participative supervisory style.

\section{Leadership Effectiveness in Nepal}

Lampers and Hickson in 1979 (Afful, 2002, p.4) have outlined that lack of effective leadership rank high among the causes of the affecting problems faced by management in our country. They further initiated that the organizations in this country do not generally utilize specialized staffs; decision making is mostly taken place at the top level and there are relatively few formalized rules and procedures. Bajracharya (1978) showed that Nepalese corporations have largely been failed in motivating employees. A study conducted by Pradhan (1999) on the organizational climate in the public and private enterprises in Nepal revealed that the standard for performance is higher and personal loyalty is stronger in the private organizations than in the public ones. Similarly, employees in private sectors have more fear of loosing their jobs. The study further revealed that supervisors in private sectors desire freedom at work. Another study conducted by Suwal (1998) showed that a majority (59 percent) of the Nepalese public enterprises' CEOs is introverted and another overwhelming majority (81 percent) of CEOs prefers doing things over and over again without doing much way to flexibility and creativity. In his study Suwal further found no significant difference between personality types of effective and ineffective CEOs and no particular managerial type of personality associated with the effectiveness of performance that could be established. Majority of Nepalese CEOs are found to be defenders or upholders of the existing system. According to Suwal (1998) highly structured relationship in Nepalese organizations tends to be authoritarian and paternalistic than supportive.

\section{Research Design}

Qualitative analytical method has been adopted throughout the study. Primary data, collected through structured questionnaire, has been used as per the requirement of the study. Five set of questions were designed to measure leadership on five independent variables i.e. vision, empowerment, communication, task or relationship orientation and locus of control. Likert Scale was found more suitable for this kind of study (Wolf and Pant, 2003). Respondents had been chosen on non probabilistic method. 120 numbers of questionnaires were distributed in total. A total of 75 respondents returned their answer sheets which came as 62.5 percent of the overall respondents. A total of 44 numbers of questionnaires distributed to the banks, 40 to hotels and 36 to the airlines, of them 29, 24 and 22 respondents returned their response respectively which comes as 65.9 percent, 60 percent and 61.11 percent on each sectors. The study is carried out on the basis of the following null 
hypotheses:

\section{Hypotheses}

H01: There is no significant difference between managers working in the high performing and low performing organizations with regard to the score obtained by them on vision scale.

H02: There is no relationship between empowerment and performance of the organizations.

H03: There is no relationship between performance of the organizations and the response made by them on communication scale.

H04 : There is no relation between managers working in high performing organizations and low performing organizations with regard to task or relationship measures.

H05: There is no relationship between empowering and communicating managers with their locus of control i.e. no correlation.

\section{Empirical Analysis}

While testing hypothesis I, Significant Mean Difference between Vision and Performance (Measured through ANOVA), the probability of $F$ statistics found to be $p>0.05$ indicates that the alternative hypothesis con not be substantiated. Hence there was no significant difference between managers working in high performing and low performing organizations with regard to the score obtained by them in aggregate vision scale constituted of five different questions. This denotes that in Nepalese service organizations relation between vision and organizational performance could not be established i.e. factors other than visions were responsible for the performance of the organizations.

The probability of the Pearson Correlation $(r=0.36)$ is less than the significance $(\mathrm{p}=0.001<0.01)$ level thus the null hypothesis is rejected with 99 percent of confidence level while measuring Correlation between Mean Response on Empowerment scale and Performance for Hypothesis II. This supports alternative hypothesis which means managers in high performing organizations are significantly more empowering than the managers in low performing organization. The positive correlation of 0.361 shows that there is moderate level of relation between performance and empowerment within the organizations i.e. high performing organization have higher empowerment and low performing organizations have lower empowerment.

Measuring Correlation between Performance and Communication of the Organizations, the probability of correlation is greater than 0.05 ( $p>0.05$, one tailed) at 95 percent level of significance, hence it is not significant and the alternative hypothesis could not be substantiated for Hypothesis III. This means that relationship between performance and the communication level within the organizations could not be established.

The alternative hypothesis could not be substantiated for Hypothesis IV while measuring through the Pearson Correlation between Performance and Task or Relationship Orientation. Managers working in high performing and low performing organizations show similar attributes with regard to the task or relationship orientation. Null hypothesis is accepted as probability of the correlation $(r=0.09)$ is $p=0.22$ which is greater than 0.05 level of significance. Positive correlation of 0.09 which is almost near to zero shows almost no 
relationship indicating managers working in high performing organizations are not significantly different from managers in low performing organizations. This tells us that still Nepalese managers even in high performing organization do not understand well the benefits of having good interpersonal relationship with employees. Hence their overall attitude is inclined toward task orientation.

Pearson Correlations between Empowerment and Communication with Locus of Control with less than moderate level of positive correlation of 0.244 with significance of $p$ $(0.018)<0.05$ (one tailed) the null hypothesis is rejected for Hypothesis V which indicates locus of control has positive correlation with empowerment and communication. This thus shows that managers with high score in empowerment and communication scale also show high on locus of control i.e. they have internal locus of control.

Mean response obtained from the managers in vision scale is 3.83 which is near to 4 . This means that managers have moderate level of vision for their organizations. Again the data shows similar picture on empowerment scale within Nepalese service organization with hotels slightly having larger mean response of 4.06 . With mean of response 3.7 on communication indicates near to moderate level of effectiveness. The mean of aggregate task or relationship scale stood at 3.57 which can not be admitted as a satisfactory score. The aggregate locus of control mean of 3.82 is shown quite near to moderate level which expresses that the leaders here have almost moderate inward locus of control.

\section{Study Results}

No significant difference was found between managers working in high performing and low performing organizations in the vision scale. This indicated that other factors than the visions are responsible for the performance of these organizations. This supported the researcher's observation of very few organizations using written form of vision to give their organizations distinct direction (however, management here was found using many vision like slogans). Hence the study recommends using modern concepts in management and applying written form of vision statements to communicate a clear guidance for the employees in the future. Moderate level of relation between performance and empowerment within the organizations was found, indicating that the high performing organizations have higher empowerment and low performing organizations have lower empowerment. Hence organizations here are recommended to empower their employees for better results. The relationship between performance and the communication level within the organization could not be established. These organizations under the study are advised to correct the communication process by encouraging free flow of communication. Very weak positive correlation of 0.09 between managers working in high performing organizations and low performing organizations bear no significant confidence level on task or relationship scale. This exposes the truth that the Nepalese managers, regardless of high performing or low performing organizations, do not understand well the benefits of having good interpersonal relationship with employees. Nepalese managers are hence suggested to give attention on building harmonious relationship with employees as well as paying attention to the task. It was found out that managers with high score in empowerment and communication scale also showed high score locus of control i.e. they have internal locus of control. This reality has recommended managers to boost up their internal locus of control. The findings with 
the mean values of 3.83 and $3.96,3.70,3.87$ and 3.82 on vision, empowerment, communication, task/relationship orientation and locus of control scales respectively are all less than the moderate level of leadership effectiveness. This reveals the fact that there is a high need for the managers here to work hard on each aspects of the leadership.

\section{REFERENCES}

Afful, Ken (2002). 'Organization in the South Need New Generation Leaders', The Organization Quarterly Journal, June-Sept, IDMS, Kathmandu.

Bajracharya, Ratna R. (1978). Employee Motivation in Nepalese Corporations, an unpublished thesis submitted for MBA degree to the Faculty of Business Administration, Commerce and Public Administration, TU, Kathmandu

Fleet, David D. Van and Peterson, Tim O, (1994). Contemporary Management. place Houghton Mifflin Co.

Luintel, Tirtha Raj (2001). A Study of Politico-Psychological Leadership Trends Among the Post Graduate Students of University Campus T. U., Nepal, an unpublished thesis for the Ph. D. Degree in Psychology submitted to the Faculty of Humanity and Social Sciences, TU, Kirtipur, Kathmandu

Pradhan, Anjir Man (1999). Organizational Climate in the Public and Private Enterprises in Nepal, an unpublished thesis for the Ph. D. Degree for the Faculty of Management, TU, Kathmandu

Robbins, Stephen P. (2001). Organizational Behavior(9thedn.), Delhi, India. Pears Education.

Schermerhorn, John R., Jr., (2004). Core Concept of Management, place, John Wiley \& Sons, Inc.

Suwal, Dr. Rajendra (1998). Nepali CEOs- The Good The Bad and The Mediocre, Organization Development Centre (ODC), Kathmandu

The Blackwell Encyclopedic Dictionary of Organizational Behavior, UK 298. Blackwell Publishers, p 298.

Wolf, Howard K. and Pant, P. R. (2003). Social Science Research and Thesis Writing (3rd edn.), Kathmandu. Buddha Academic Enterprises. 